Article

\title{
Hydro-Climatic Variability: A Characterisation and Trend Study of the Awash River Basin, Ethiopia
}

\author{
Mahtsente Tibebe Tadese ${ }^{1, *(1)}$, Lalit Kumar ${ }^{1}\left(\mathbb{D}\right.$, Richard Koech ${ }^{2}$ and Birhanu Zemadim ${ }^{3}(\mathbb{C}$ \\ 1 Environment and Rural Science, University of New England, Armidale 2351, Australia; lkumar@une.edu.au \\ 2 Department of Agriculture, Science and Environment, Central Queensland University, Bundaberg Campus, \\ Bundaberg QLD 4670, Australia; r.koech@cqu.edu.au \\ 3 International Crops Research Institute for the Semi-Arid Tropics (ICRISAT), BP 320, West and Central Africa \\ Regional Hub, Bamako 00223, Mali; Z.Birhanu@cgiar.org \\ * Correspondence: mahtsenti@gmail.com; Tel.: +61-470-337-312
}

Received: 21 March 2019; Accepted: 25 April 2019; Published: 27 April 2019

check for updates

\begin{abstract}
The objective of this study was to characterize, quantify and validate the variability and trends of hydro-climatic variables in the Awash River Basin (ARB) in Ethiopia using graphical and statistical methods. The rainfall and streamflow trends and their relationships were evaluated using the regression method, Mann-Kendall (MK) test and correlation analysis. The analysis focused on rainfall and streamflow collected from 28 and 18 stations, respectively. About $85.7 \%$ and $75.3 \%$ of the rainfall stations exhibited normal to moderate variability in annual and June to September rainfall, respectively, whereas $96.43 \%$ of rainfall stations showed high variability in March to May. The MK test showed that most of the significant trends in annual rainfall were decreasing except in two stations. These research findings provide valuable information on the characteristics, variability, and trend of rainfall and streamflow necessary for the design of sustainable water management strategies and to reduce the impact of droughts and floods in the ARB.
\end{abstract}

Keywords: Awash Basin; hydro-climate; variability; streamflow; trend

\section{Introduction}

In recent decades, concerns around water resources and climate change have gained global significance. Water resources are exposed to high spatial and temporal hydro-climatic variability, leading to major challenges affecting the economic development [1]. Climate change and an altered water supply regime have necessitated the need to investigate the relationships between climate and water resources. The availability and accessibility of water resources are mainly reliant on climate and environment of the area. The rainfall variability, alteration in temperature and other climatic variables significantly affect the variation in streamflow level and time of hydrologic events [2]. The level of streamflow will be affected by several factors which include rainfall characteristics, soil physical properties, watershed factors and human activities [3].

Water resources in Ethiopia are highly vulnerable to climate and hydrological variability due to its topography and human-induced factors, such as land degradation, high population density and water management practices [4-6]. Ethiopia has twelve river basins, out of which the Awash River Basin (ARB) is intensively utilized and environmentally vulnerable. Freshwater biodiversity, basin habitat and human livelihood are exposed to a risk due to over-abstraction of river water, population growth and poor water management [7]. The Intergovernmental Panel on Climate Change (IPCC) Africa report indicated that in the highlands of Ethiopia, where there is a high and heterogeneous topography, rainfall and floods are expected to increase during the final period of the 21st century [1]. 
Previous studies have attempted to characterise rainfall and streamflow in different parts of Ethiopia [8-11]. The study by [12] in the highlands of Ethiopia; [13] in the Blue Nile; and [14] in the Rift Valley of Ethiopia, showed an increase in annual temperature and a decline in rainfall trends in growing seasons, but the pattern of annual rainfall indicated no significant and clear trend. Similar studies have been performed in the ARB indicating a non-statistically significant annual rainfall trend with the exception of a negative non-significant trend in a few rainfall stations $[15,16]$. Furthermore, the study by [17] showed an increasing trend in mean annual rainfall in ARB, and a significantly increasing trend in two stations, while a slightly decreasing trend occurred in the other two stations.

Even though numerous studies related to climate and hydrology in different parts of Ethiopia have been undertaken, little attention has been given to the characteristics and variability of rainfall, temperature and river flow in the ARB. The ARB is the most utilized and developed basin in Ethiopia; however, documentation and data availability are the major problems in this basin [18]. This might be due to the focus of the Ethiopian Government on the Blue Nile River Basin. All water-based developments in the ARB were established with little knowledge about the river water availability, and without proper water resources management strategy [16]. Additionally, some studies in the ARB used temperature, rainfall, and land use data which were not sufficient and representative of the whole area. For example, the study by [19] covered only $7 \%$ of the ARB, upstream of Koka Dam because the downstream flow is highly affected by dam and large irrigation lands. Similarly, the study by [17] analysed only four rainfall and four streamflow stations in ARB, while three of the streamflow stations were located in the Upper Awash Basin. Furthermore, the characteristics of hydro-climatic variables and their trends in the ARB of Ethiopia have not been fully studied and quantified. Therefore, investigating and understanding the characteristics, variability, and the trend of hydro-climatic variables for ARB is important.

The objective of this study was; therefore, to characterize, quantify and validate the variability and trends of hydro-climatic variables in the ARB. The findings of this study will lead to a better understanding of rainfall and water variability in the ARB, including patterns, trends and the extent of the changes. It will also provide guidelines on the appropriate season to implement water saving techniques and help to manage risks from extreme events. In particular, the results of this study will provide valuable information necessary for planning and designing sustainable water management approaches that reduce the impact of droughts and floods in ARB.

\section{Materials and Methods}

\subsection{Study Area}

The study was conducted in the ARB of Ethiopia which is located between latitudes $7^{\circ} 53^{\prime} \mathrm{N}-12^{\circ} \mathrm{N}$ and longitudes $37^{\circ} 57^{\prime} \mathrm{E}-43^{\circ} 25^{\prime} \mathrm{E}$ (Figure 1). The basin has an area of $112,696 \mathrm{~km}^{2}$, with an annual flow of 4.9 billion cubic metres $\left(\mathrm{BM}^{3}\right)$ and $0.14 \mathrm{BM}^{3}$ estimated groundwater potential [20]. The total length of Awash River is $1200 \mathrm{~km}$ and starts flowing at an altitude of $3000 \mathrm{~m}$ in the Central Highlands of Ethiopia and flows through different locations, and finally joins Lake Abe at a $250 \mathrm{~m}$ altitude above mean sea level (AMSL). The basin covers diverse parts of the country, namely: Amhara, Oromia, Afar, Dire Dawa and Addis Ababa. The ARB has a potentially irrigable land of about 206,000 ha [16].

There are three main dams in Awash River Basin-Koka, Kessem and Tendaho. Koka Dam is located in the upper Awash and is important for hydropower generation and irrigation development. The Koka reservoir is a main source of water supply for users of downstream dams from Amibara to Gewane. Kessem and Tendaho dams are located in the Middle and Lower Awash, respectively, for irrigation and household water supply. Major crops grown in the area are sugarcane, vegetables, fruit and cotton. The Awash River gives regular irrigation water to productive and larger agricultural areas. Moreover, it generates hydropower energy and provides water supply for different towns and cities along its course, which includes Legadadi, Gefersa, Dire and Aba-Samuel reservoirs. A number of large and small irrigation schemes are found in ARB, which includes Wonji sugar factory and Wonchiti 
irrigation project in Upper Awash (around 33,900 ha) and Tendaho irrigation project (Dubti, Assayita, Afambo vegetable and sugarcane corporation) in Lower Awash (around 62,500 ha). Large and small irrigation schemes in the Middle Awash (around 55,000 ha) include Abadir and Merti canal, Amibara irrigation, Tebli irrigation project, Nura hera, Gewane and Kessem [21,22].

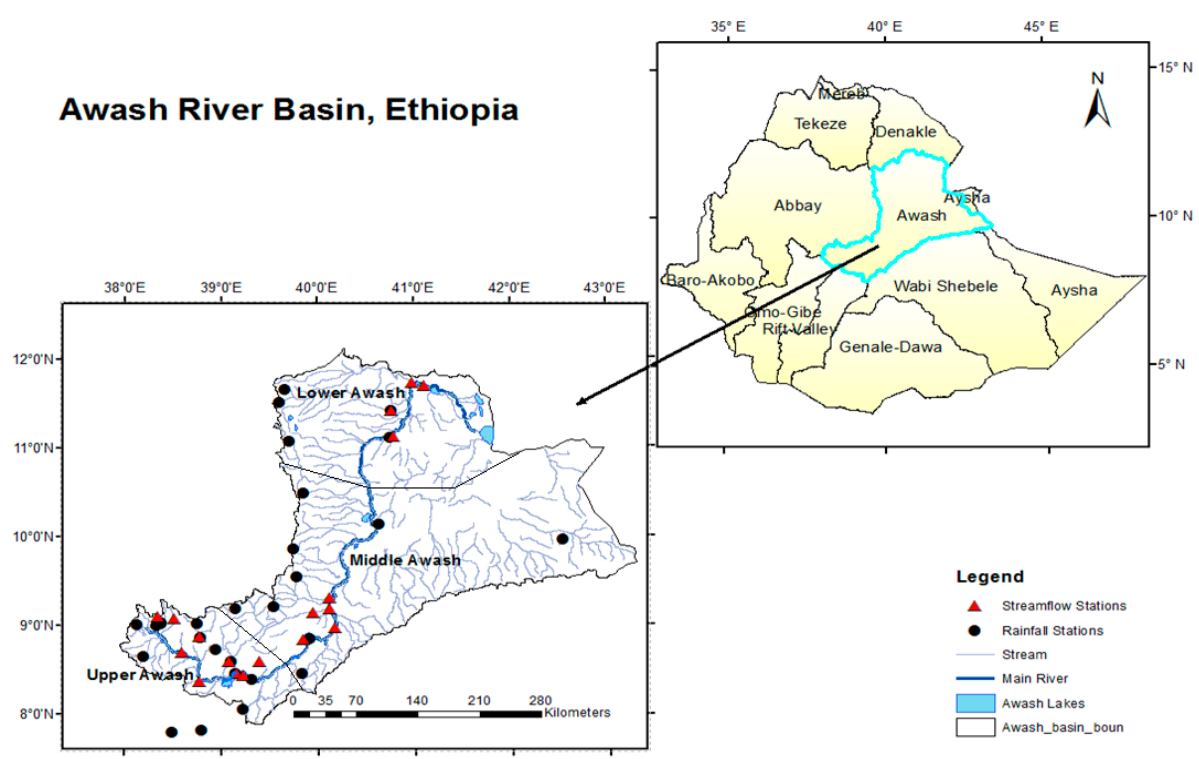

Figure 1. Location of the study area.

\subsection{Data Pre-Processing}

Digital Elevation Model (DEM) (30 m resolution) of ARB and the hydrological shape files obtained from the Ministry of Water, Irrigation, Electric and Energy (MWIEE) in Ethiopia were used in ArcGIS to delineate the study area. The long-term hydro-climatic data were collected from the National Meteorology Agency (NMA), MWIEE and Ethiopian Institute of Agricultural Research (EIAR). The current analysis focused on the two hydro-climatic variables: rainfall and streamflow collected from 28 and 18 stations, respectively (Figure 1). The rainfall and streamflow stations were selected based on three criteria: long-term data availability, percentage of missing data and representativeness of the basin. The duration selected was more than 30 years, from 1954 to 2016 for rainfall except for two stations, and more than 25 years (1970-2016) for streamflow except for one station. In this study, sites with less than $10 \%$ of the missing data were selected for both rainfall and streamflow stations, but three rainfall stations and two streamflow stations were accepted with missing values of less than $15 \%$ in order to have a better representative station distribution within the basin. Missing gaps greater than $5 \%$ were completed using normal ratio method and simple linear regression. The normal ratio method was used to complete missing data in rainfall stations that have a closer nearby rainfall station (Equation (1) [23]).

$$
P_{x}=\frac{\bar{P}_{x}}{n} \sum_{i=1}^{n} \frac{P_{i}}{\bar{P}_{i}}
$$

where $\bar{P}_{x}$ and $\bar{P}_{i}$ are annual average rainfall at a station with missing value and neighbouring gauges respectively, $P_{i}$ is the rainfall in the neighbouring gauge and $n$ is the number of neighbouring stations.

Primary data visualization of rainfall and streamflow was conducted with time series plots, and then normality, homogeneity and outlier tests were performed using Excel, Sigma XL and XLSTAT software (SigmaXL Version 8.1, Company: SigmaXL Inc. 305 King Street West, Suite 503 Kitchener, Ontario N2G 1B9, Canada; XLSTAT 2018.2, Company: Addinsoft Inc 10-34 44th drive, 2 Floor Long Island City NY 11101, United States). The normality was analysed using Skewness, Kurtosis and 
$Z$-value. Critical values of $Z$-score were $\pm 1.65, \pm 1.96$, and \pm 2.58 at $0.1,0.05$ and $0.01 \%$ significance level, respectively.

In the present study, annual, monthly and seasonal data were arranged from daily data of rainfall and streamflow. The basin was subdivided into three based on their location and physical factors: Upper Awash covering the upstream parts from Koka Dam; Middle Awash including areas between Koka and Awash station; and lastly, Lower Awash covering stations between Awash, Tendaho and the eastern stations [24,25] (Figure 1). The stations included in each sub-basin are shown in Appendix A: Table A1. A similar time series was required to evaluate the relation of inter-annual and temporal variability over different locations. One of the major challenges in ARB is less data availability with varying duration. The rainfall and streamflow data have a different period with a different start and end date. In order to address this challenge and to get representative stations within ARB, stations with the similar period were clustered into one group. Therefore, depending on the duration of the time series, streamflow and rainfall stations were clustered into three and four groups respectively (Appendix A: Tables A2 and A3). The period of data used in each rainfall station groups was 60 years (1954-2013) for Group 1, 52 years (1965-2016) for Group 2, 30 years (1975-2004) for Group 3 and 28 years (1985-2012) for Group 4. The period of data used in each streamflow station groups was 35 years (1975-2009) for Group 1, 26 years (1983-2008) for Group 2 and 21 years (1981-2001) for Group 3. Furthermore, the rainfall and streamflow gauge stations, having both rainfall and streamflow data, were selected to analyse the relationship between rainfall and streamflow. Moreover, Koka and Kessem streamflow stations are regulated at Koka and Kessem reservoirs, respectively, while Tendaho and Mille stations are monitored at Tendaho reservoir.

\subsection{Statistical Analysis}

The hydro-climatic data analysis was undertaken to characterise, quantify and validate the variability and trend in the basin. The variability and trend can be tested using different statistical and graphical methods. In this study, the coefficient of variation $(\mathrm{CV})$, standardised anomaly index (SAI) and graphical methods were used. The rainfall and streamflow trends and their relationships were evaluated using the regression method, Mann-Kendall (MK) test, Sen's slope estimator and correlation analysis (see the subsection below for further details).

The $C V$ is a statistical measure that shows the variation of data about the mean; it is the ratio of standard deviation to the mean (Equation (2)). In this study, a $C V$ of $<20, \geq 20 \leq 30$, and $>30$ was considered as normal, moderate and highly variable, respectively. In previous studies, the $C V$ was used to characterise the variability of rainfall $[8,15,26]$.

$$
C V=\frac{\sigma}{\bar{X}}
$$

where $\sigma$ and $\bar{X}$ denote standard deviation and mean of rainfall, respectively.

The SAI indicates a measure of distance between the data and its mean (Equation (3)). It shows the probability of existence of an observed rainfall amount related with the long-term mean rainfall. Examples of previous studies that have used $S A I$ to analyse rainfall variability include $[12,26,27]$.

$$
S A I=\frac{(x-\bar{X})}{\sigma}
$$

where $x$ is rainfall, $\bar{X}$ and $\sigma$ denote the mean standard deviation of the rainfall data.

\subsection{MK Test and Sen's Slope}

There are different parametric and non-parametric trend-detecting techniques. A non-parametric trend test, the MK test $[28,29]$, is the widely preferred method, due to its independence in the data distribution and not being affected by missing values and outliers [30]. The probability of MK trend test 
to give a significant trend increases when serial autocorrelation exists; therefore, lag1-autocorrelation was tested for rainfall and streamflow on annual and seasonal periods before Mann-Kendall trend test [30,31]. A non-significant autocorrelation was obtained in annual rainfall and streamflow for twenty-two and fourteen stations, respectively. For stations that showed significant autocorrelation, the trend was tested and verified using linear regression. Once the hydro-climatic trends of stations were analysed, the common duration of record in the same stations were selected to investigate the relationship of their trends using correlation. The test statistic $S$ was calculated by:

$$
S=\sum_{i=1}^{n-1} \sum_{j=i+1}^{n} \operatorname{sgn}\left(x_{j}-x_{i}\right)
$$

where $x_{j}$ denote the consecutive data values, $n$ denotes the number of the data set, and

$$
\operatorname{sgn}(\theta)= \begin{cases}1 & \text { if } \theta>0 \\ 0 & \text { if } \theta=0 \\ -1 & \text { if } \theta<0\end{cases}
$$

The variance, $\operatorname{Var}(s)$ was calculated by

$$
\operatorname{Var}(s)=\frac{n(n-1)(2 n+5)-\sum_{i=1}^{m} t_{i}\left(t_{i}-1\right)\left(2 t_{i}+5\right)}{18}
$$

where $n$ denote the number of observations, $\mathrm{m}$ is the number of tied groups and $t_{i}$ is the number of ties of the sample at time $i$.

The standard test statistic Zs was calculated using:

$$
Z s=\left\{\begin{array}{cl}
\frac{S-1}{\sqrt{\operatorname{Var}(S)}} & S>0 \\
0 & S=0 \\
\frac{S+1}{\sqrt{\operatorname{Var}(S)}} & S<0
\end{array}\right.
$$

In a Zs test, the null hypothesis implies no trend, whereas the alternative hypothesis means a significant change has occurred over time [30,31]. The values of $Z s>0$ and $Z s<0$ indicate an increasing and decreasing trend, respectively. Moreover, a significant trend at 0.05 and 0.01 significance levels exist when the $/ Z />1.96$ and $/ Z />2.58$, respectively [32]. In this study, 0.05 and 0.01 significance levels were considered to analyse the hypothesis.

The Sen's slope estimator is a non-parametric analysis to estimate the magnitude and direction of the trend in the sample of $N$ pairs of data [32]. The slope $\left(Q_{i}\right)$ was calculated by

$$
Q_{i}=\frac{x_{j}-x_{k}}{j-k} \text { For } i=1, \ldots, N,
$$

where $x_{j}$ is the data values at $j$ and $x_{k}$ presents the data values at $k(j>k)$. When there is one data point in each time period, then $N=\frac{n(n-1)}{2}$, where $n$ is the number of time periods. But, if there are more data points then, $N<\frac{n(n-1)}{2}$, where $n$ is the total number of observations. The values of $N$ are arranged from smallest to biggest. Then, the median of slope or Sen's slope estimator $\left(Q_{m i d}\right)$ was caluclated by

$$
Q_{\text {mid }}=\left\{\begin{array}{c}
Q_{(N+1) / 2,} \text { if } N \text { is odd } \\
\frac{Q_{[N / 2]}+Q_{[(N+2) / 2]}}{2}, \text { if } N \text { is even }
\end{array}\right.
$$

When the value $Q_{\text {mid }}>0$, it indicates an increasing trend while $Q_{\text {mid }}<0$ represents a decreasing trend. 


\section{Results}

\subsection{Hydro-Climatic Characteristics of the ARB}

\subsubsection{Monthly and Seasonal Characteristics of Rainfall}

The mean monthly rainfall of the stations in the Upper Awash basin varied from 6 to $223 \mathrm{~mm}$ in the period 1975-2004 (Figure 2). Comparatively, the monthly rainfall was low from October to February, but started to increase in June (Figure 2). Moreover, relatively intensive rainfall was received between June and August, with the maximum mean monthly rainfall received in July at the Tulubolo station. The minimum monthly rainfall was recorded at Tulubolo in December and in all stations the lowest rainfall occurred in November and December. In the Middle Awash, the mean monthly rainfall varied from 13 to $222 \mathrm{~mm}$ (Figure 2). The mean monthly rainfall in the Lower Awash varied from 16 to $186 \mathrm{~mm}$ (Figure 2). The minimum rainfall was recorded in December and the maximum in August.

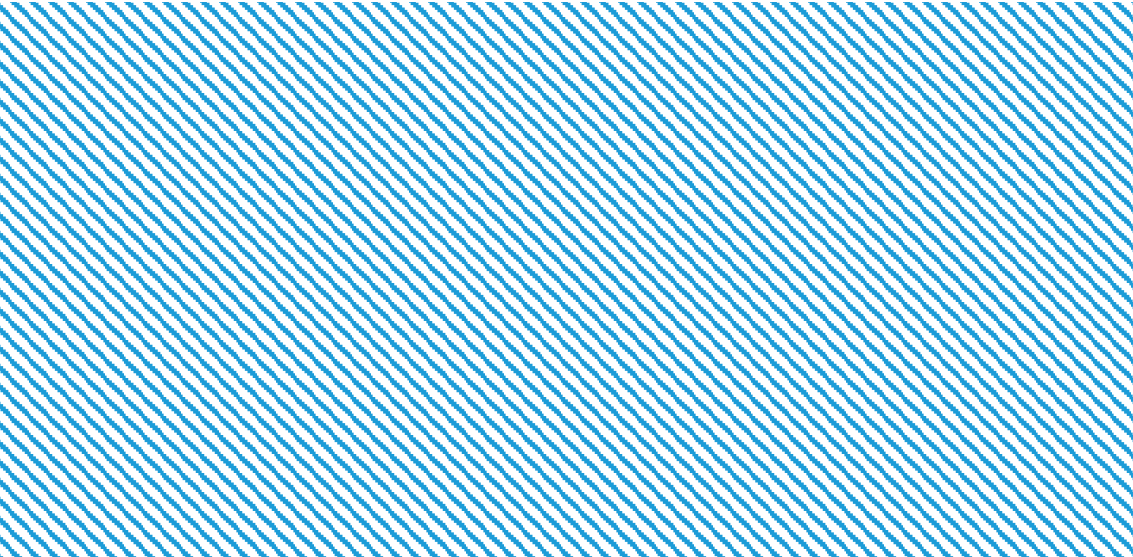

Figure 2. The mean monthly rainfall (mm) at Upper, Middle and Lower Awash River Basin (ARB).

\subsubsection{Inter-Annual and Temporal Rainfall Variability}

Figure 3 shows annual rainfall of the 28 rainfall stations in the ARB; the annual rainfall varied from 281 to $1389 \mathrm{~mm}$. The Debresina and Mille stations recorded the highest and lowest annual rainfall, respectively.

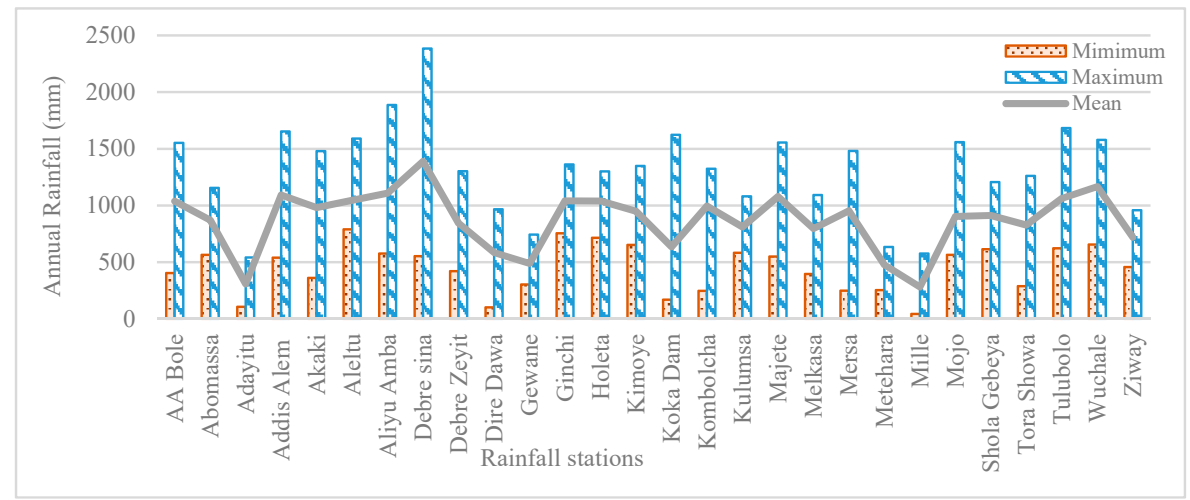

Figure 3. The annual rainfall $(\mathrm{mm})$ in ABR for the 28 rainfall stations.

Figure 4 shows the annual and seasonal rainfall variation in selected stations in Groups 1 and 2 (see Annex 2). In Group 1, annual rainfall varied from 375 to $1552 \mathrm{~mm}$ at Dire Dawa and Addis Ababa stations, respectively. The variability of Group 1 stations presented a similar increasing and decreasing pattern except for a few years with extremely high rainfall. High rainfall was recorded at Akaki and Addis Ababa in 1969 and 1996, respectively. In Group 1, both the graphical and linear trend in annual 
rainfall indicated a negative trend except at Dire Dawa. In Group 2, the annual rainfall varied from 169 at Koka Dam to $2384 \mathrm{~mm}$ at Debresina.
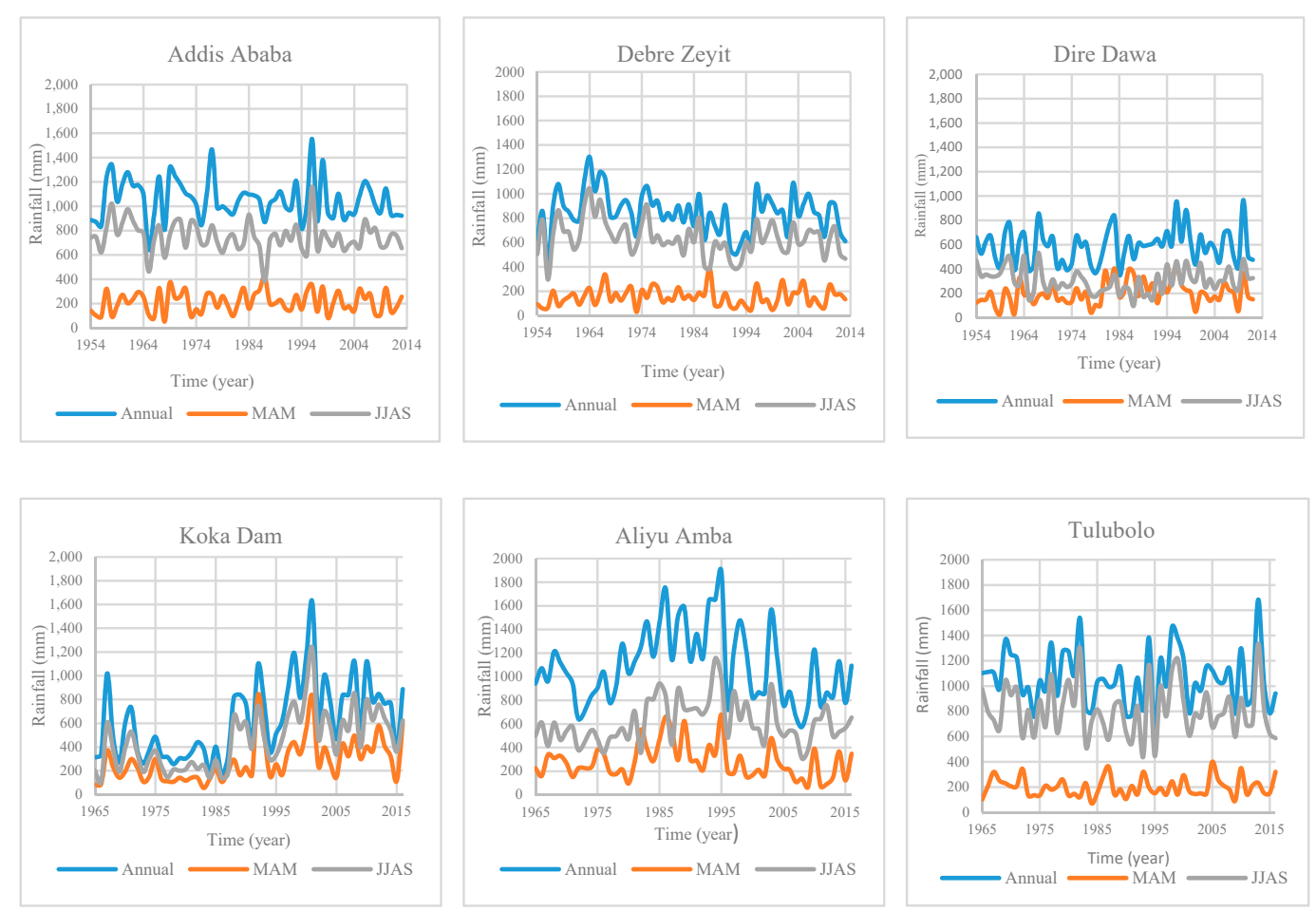

Figure 4. Seasonal temporal variability of rainfall $(\mathrm{mm})$ in selected stations in Groups 1 and 2 (JJAS-June to September; MAM-March to May).

The variability of rainfall in Groups 3 and 4 is shown in Figure 5. In Group 3, the annual rainfall varied from $44 \mathrm{~mm}$ at Mille to $1590 \mathrm{~mm}$ at Aleltu, while the annual temporal rainfall variability indicated a similar pattern of rise and decline in a majority of stations. For example, in 1980 and 1997, decreasing annual rainfall was recorded in all stations except Wuchale and Majete; however, there was an increase in 1988 except at the Wuchale station. In Group 4, the annual rainfall varied from 107 at Adiaytu to $1361 \mathrm{~mm}$ at Shola Gebeya. Stations in this group showed temporal variation with a different pattern; an increase in some and decrease in others. For instance, in 1995 six stations presented a decreasing pattern while there was an increase in three others.

The summary of statistical analysis for the 28 rainfall stations located in ARB is shown in the Table 1 . The annual skewness showed that $75 \%$ of the stations were approximately symmetrical while $17.86 \%$ were moderately symmetrical. Moreover, all stations indicated a Z-score of Skewness and Kurtosis closer to zero, indicating no significant difference from normality. In about half the stations, the annual mean rainfall had a $C V$ of $<20$. On the other hand, $35.71 \%$ and $14.29 \%$ of the stations had a CV of $20-30 \%$ (moderate variability) and $>30 \%$ (high variability), respectively (Table 1 ). In this study, high annual rainfall variability was detected in four stations: Adaitu, Debresina, Mille and Koka dams. The seasonal variability was also tested in order to evaluate the detailed rainfall characteristics that occurred in the period. The two rainfall seasons selected were June to September (JJAS) and March to May (MAM). The JJAS rainfall showed slightly similar result as that of the annual rainfall variability. Out of twenty-eight rainfall stations, $21.43 \%$ of the stations showed a $C V$ which was less than $20 \%$, while $53.57 \%$ of stations indicated a $C V$ between $20-30 \%$ and $25 \%$ of stations showed a $C V$ which was greater than $30 \%$. Seven stations showed high rainfall variability in the JJAS seasonal period, and, out of these, four stations indicated the same trend in the annual time series. However, the period MAM rainfall showed $96.43 \%$ of the stations had a $C V>30$ (Table 1). One station (Abomassa) showed a moderate $C V$, but other stations indicated high rainfall variability in the period of MAM. 

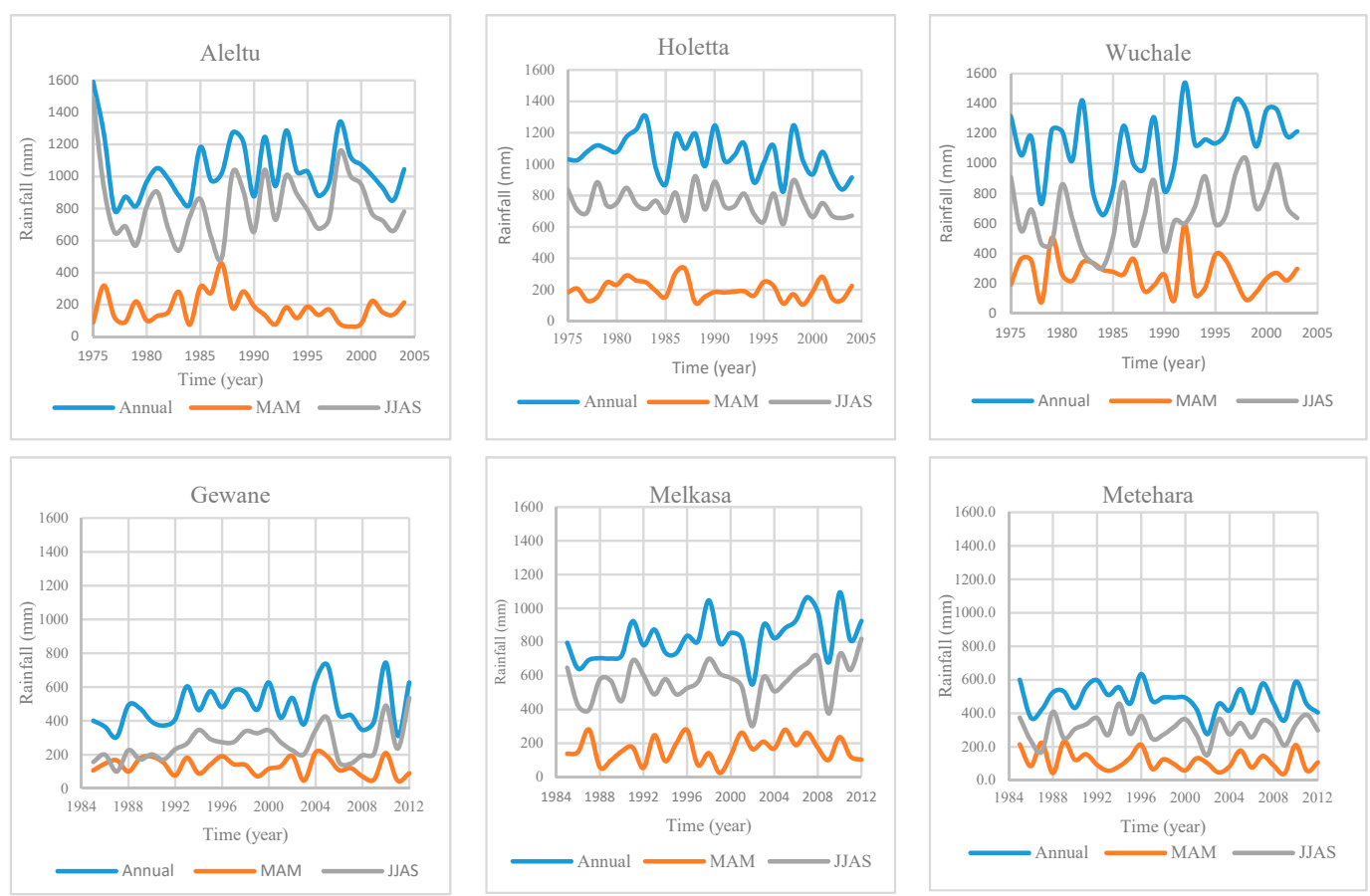

Figure 5. Seasonal temporal variability of rainfall in selected stations in Groups 3 and 4 (MAM and JJAS).

Table 1. Summary of descriptive statistics of rainfall in ARB.

\begin{tabular}{|c|c|c|c|c|c|c|c|c|c|}
\hline \multirow[t]{2}{*}{ No } & \multirow[t]{2}{*}{ Station } & \multicolumn{4}{|c|}{ Annual } & \multicolumn{2}{|c|}{ MAM } & \multicolumn{2}{|c|}{ JJAS } \\
\hline & & $\begin{array}{l}\text { Mean } \\
(\mathrm{mm})\end{array}$ & $C V(\%)$ & Kurtosis & Skewness & $\begin{array}{l}\text { Mean } \\
(\mathrm{mm})\end{array}$ & $C V(\%)$ & $\begin{array}{l}\text { Mean } \\
(\mathrm{mm})\end{array}$ & $C V(\%)$ \\
\hline 1 & AA Bole & 1037.91 & 18.16 & 1.77 & -0.10 & 210.86 & 42.75 & 737.60 & 18.28 \\
\hline 2 & Abomassa & 870.42 & 16.59 & -0.52 & 0.20 & 229.04 & 29.38 & 477.85 & 23.55 \\
\hline 3 & Adayitu & 308.08 & 31.63 & 0.15 & 0.01 & 91.95 & 62.21 & 149.41 & 53.35 \\
\hline 4 & Addis Alem & 1092.63 & 21.84 & -0.37 & -0.05 & 223.61 & 36.72 & 788.52 & 24.16 \\
\hline 5 & Akaki & 982.43 & 20.75 & 0.69 & -0.19 & 201.42 & 44.45 & 713.14 & 22.08 \\
\hline 6 & Aleltu & 1045.91 & 17.21 & 1.09 & 0.98 & 175.64 & 50.59 & 819.18 & 24.15 \\
\hline 7 & Aliyu Amba & 1109.32 & 27.80 & -0.34 & 0.53 & 285.01 & 52.81 & 620.03 & 29.43 \\
\hline 8 & Debre sina & 1389.30 & 37.33 & -1.31 & 0.10 & 347.58 & 50.00 & 802.31 & 41.03 \\
\hline 9 & Debre Zeyit & 844.68 & 20.60 & 0.12 & -0.01 & 153.02 & 49.29 & 636.63 & 23.14 \\
\hline 10 & Dire Dawa & 584.97 & 26.46 & 0.98 & 0.00 & 200.79 & 47.11 & 305.81 & 32.47 \\
\hline 11 & Gewane & 489.69 & 24.67 & -0.68 & 0.46 & 134.31 & 39.87 & 265.26 & 38.32 \\
\hline 12 & Ginchi & 1041.47 & 13.04 & -0.20 & -0.01 & 243.36 & 34.69 & 705.10 & 16.18 \\
\hline 13 & Holeta & 1039.52 & 11.82 & 0.08 & -0.23 & 192.62 & 31.31 & 722.62 & 16.50 \\
\hline 14 & Kimoye & 948.21 & 16.71 & -0.09 & 0.25 & 210.94 & 45.69 & 652.87 & 17.14 \\
\hline 15 & Koka Dam & 636.75 & 49.55 & 0.14 & 0.69 & 278.07 & 63.86 & 462.32 & 51.57 \\
\hline 16 & Kombolcha & 994.51 & 18.18 & 4.17 & -1.31 & 225.31 & 38.91 & 645.48 & 24.11 \\
\hline 17 & Kulumsa & 810.85 & 13.78 & -0.16 & 0.08 & 251.18 & 36.68 & 449.55 & 14.43 \\
\hline 18 & Majete & 1079.94 & 19.29 & 0.79 & -0.33 & 234.67 & 40.94 & 682.70 & 27.37 \\
\hline 19 & Melkasa & 796.67 & 18.88 & 0.35 & -0.31 & 156.26 & 48.72 & 555.43 & 21.45 \\
\hline 20 & Mersa & 953.06 & 25.20 & 0.94 & -0.45 & 261.30 & 44.43 & 539.85 & 32.76 \\
\hline 21 & Metehara & 478.05 & 18.97 & 0.21 & -0.53 & 113.00 & 53.76 & 307.38 & 23.34 \\
\hline 22 & Mille & 281.78 & 42.49 & 0.07 & 0.38 & 75.79 & 71.56 & 172.82 & 54.62 \\
\hline 23 & Mojo & 903.54 & 20.98 & 2.58 & 1.03 & 158.22 & 58.61 & 677.43 & 22.21 \\
\hline 24 & Shola Gebeya & 913.21 & 15.52 & -0.57 & 0.19 & 150.88 & 46.28 & 710.95 & 19.92 \\
\hline 25 & Tora Showa & 827.62 & 26.79 & 0.08 & -0.34 & 278.17 & 39.04 & 447.22 & 29.11 \\
\hline 26 & Tulubolo & 1063.52 & 20.39 & 0.32 & 0.52 & 202.39 & 37.25 & 806.23 & 25.32 \\
\hline 27 & Wuchale & 1167.50 & 18.42 & 0.04 & -0.30 & 280.08 & 39.76 & 680.00 & 26.51 \\
\hline 28 & Ziway & 720.61 & 18.47 & -0.81 & -0.26 & 198.51 & 43.71 & 431.21 & 22.70 \\
\hline
\end{tabular}

$C V$ : Coefficient of variation 
Figure 6 shows the $S A I$ of the annual rainfall for selected rainfall stations in the ARB. The figure shows that the negative anomaly varied from $40 \%$ to $64 \%$ of the total number of observations at Holetta and Aleltu, respectively. On seasonal time series, MAM and JJAS showed a negative anomaly between $47 \%$ to $63 \%$ and $43 \%$ to $59 \%$ of the observations, respectively. The MAM rainfall displayed a higher negative anomaly at Shola Gebeya, whereas JJAS showed a higher negative anomaly at Aliyu Amba. In some stations a negative anomaly was observed in consecutive years, for example, Koka dam, Aleltu and Melkasa.
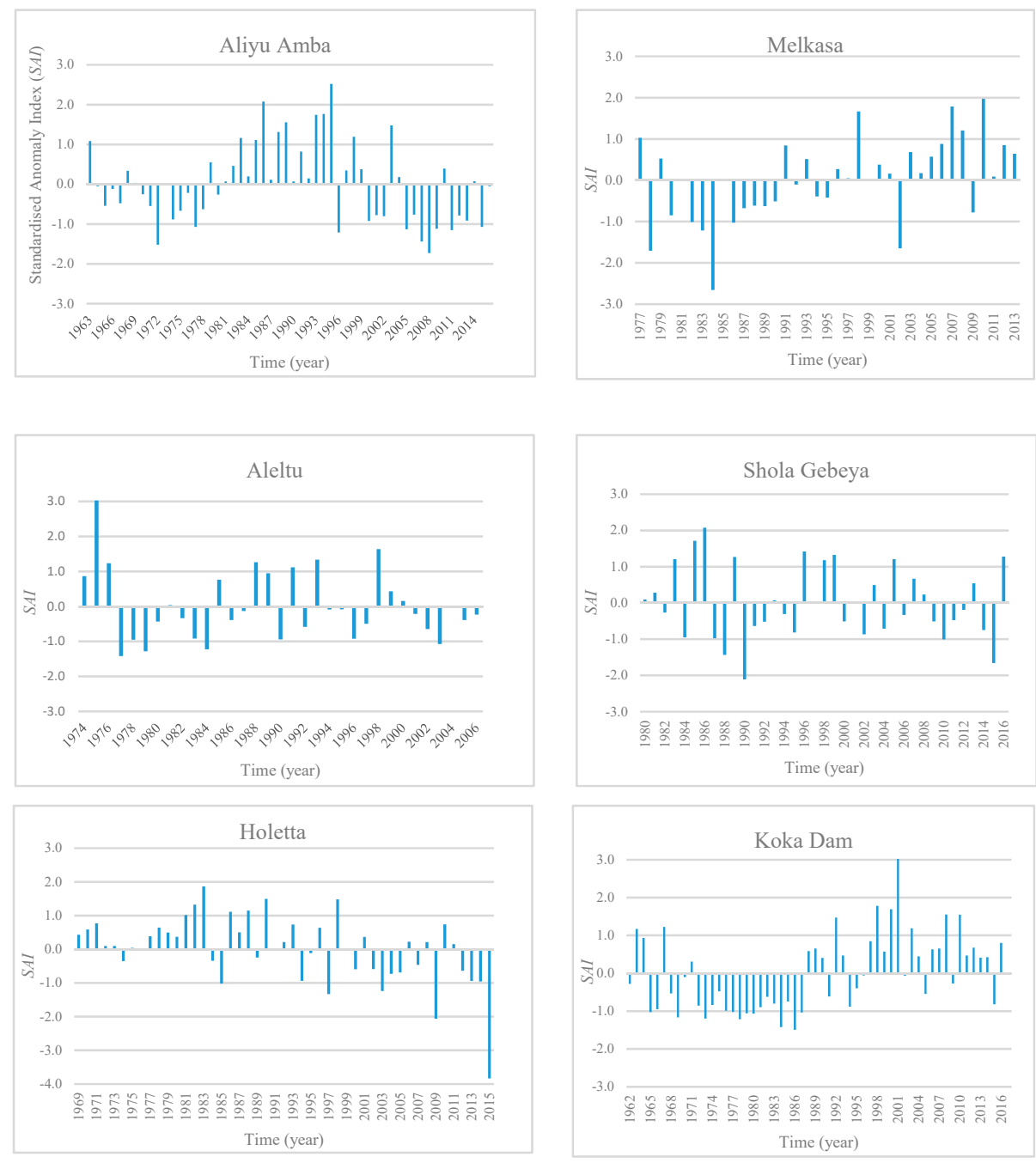

Figure 6. The annual standardised anomaly index $(S A I)$ of rainfall in selected stations in the ARB.

\subsubsection{Monthly and Seasonal Streamflow Characteristics}

The mean monthly streamflow of clustered river gauged stations in the ARB is shown in Figure 7. The Awash River discharge was low from November to mid-June, but started to increase in July (Figure 7). The highest flow was recorded in August at $63.6 \%$ of the stations, and in September for the rest of the stations. The maximum streamflow was 206.78 cubic metres per second $\left(\mathrm{m}^{3} / \mathrm{s}\right)$ in August at Hombole, while the minimum was $0.28 \mathrm{~m}^{3} / \mathrm{s}$ in February at Holetta. Group 2 hydrograph indicated that the minimum flow occurred during November to June before starting to increase in July. The maximum flow was $121.32 \mathrm{~m}^{3} / \mathrm{s}$ at Melkasedi and the minimum record was $4.07 \mathrm{~m}^{3} / \mathrm{s}$ at Akaki. Group 3 hydrograph indicated a slightly different pattern — the minimum flow was in December to February and then slightly increased in March and April; again it declined in May and June but increased in July. The results from most of these stations showed a low flow during November to June but the increase started in July. 


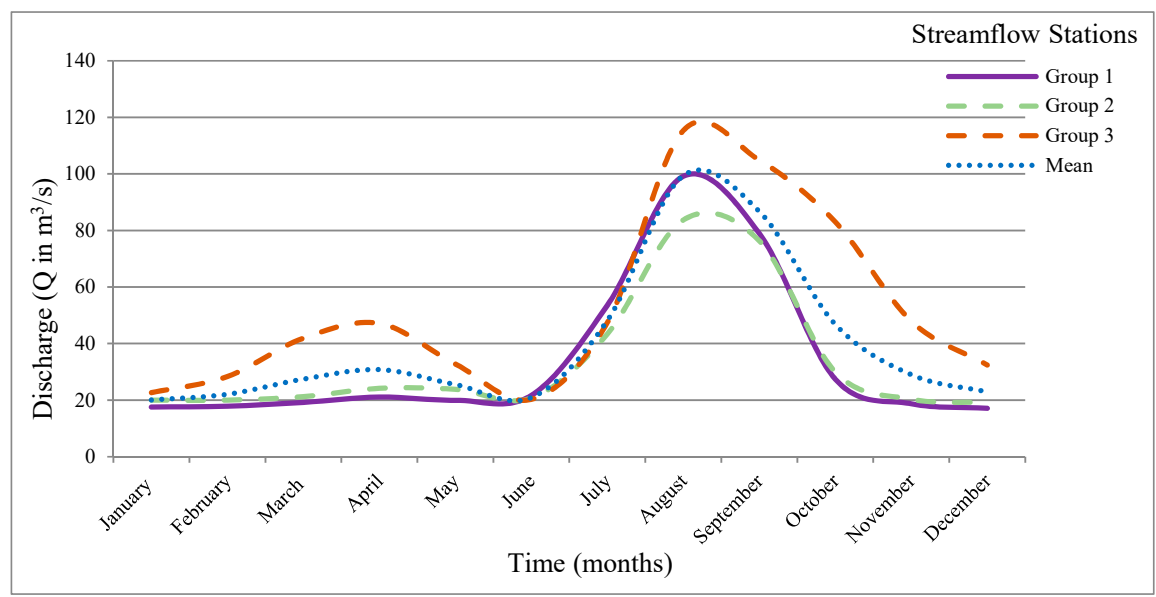

Figure 7. The mean monthly river discharge in ARB at Group 1, 2 and 3.

\subsubsection{Inter-Annual and Temporal Variability of Streamflow}

Figure 8 shows annual streamflow of 18 stations in the ARB. The annual flow varied from $1.73 \mathrm{~m}^{3} / \mathrm{s}$ at Holetta to $72 \mathrm{~m}^{3} / \mathrm{s}$ at Dubti. The maximum and the minimum annual discharge was recorded at Dubti and Holetta stations, respectively.

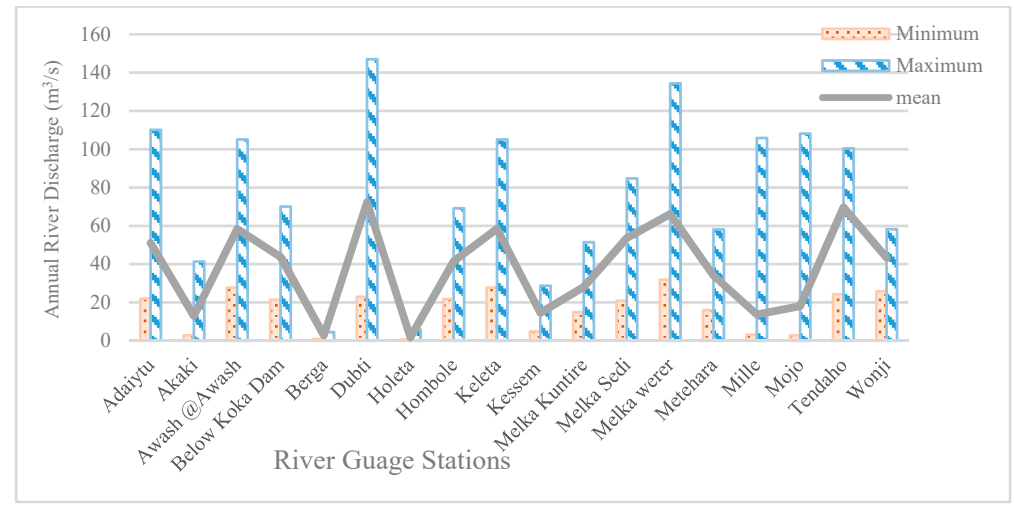

Figure 8. The annual river discharge of ARB at 18 stations.

Figure 9 shows annual streamflow variability at six stations. The hydrographs had a similar pattern on annual and MAM river discharge, except for a few years with extremely high flow records. Extreme streamflow was recorded at the Kessem and Mojo stations in 1988 and 1996, respectively. A similar increase in flow during these years was shown in all the other stations. Both the graphical and linear trend on annual streamflow illustrated a positive trend, except at Holeta, Mojo and Wonji.

The temporal streamflow variability of Groups 2 and 3 stations are presented in Figure 10. In Group 2, the annual streamflow varied from $2.89 \mathrm{~m}^{3} / \mathrm{s}$ at Akaki to $84.80 \mathrm{~m}^{3} / \mathrm{s}$ at Melkasedi (Figure 10a). Melkasedi and Metehara exhibited the same pattern of variation with moderate increase and decrease during the period of the observations. Peak flow was exhibited in 2006 at the Melkasedi and in 1993 at Metehara stations. At the Akaki station, a high temporal variability was recorded from 1992 to 2000, while the peak flow occurred in 1996. Similar to Group 1, the graphical and linear trend on annual streamflow was positive in all stations of Group 2. The hydrograph of Group 3 shows a temporal increasing and decreasing pattern, and the extreme flow was recorded at Dubti in 1992. The minimum flow at Dubti, Tendaho and Adaiytu were relatively similar and occurred in the same year, 1984. The analysis on annual flow of Group 3 demonstrated an increasing trend in all stations except at Tendaho (Figure 10b). However, in the MAM period, all Group 3 stations presented a decreasing trend except at Dubti. 

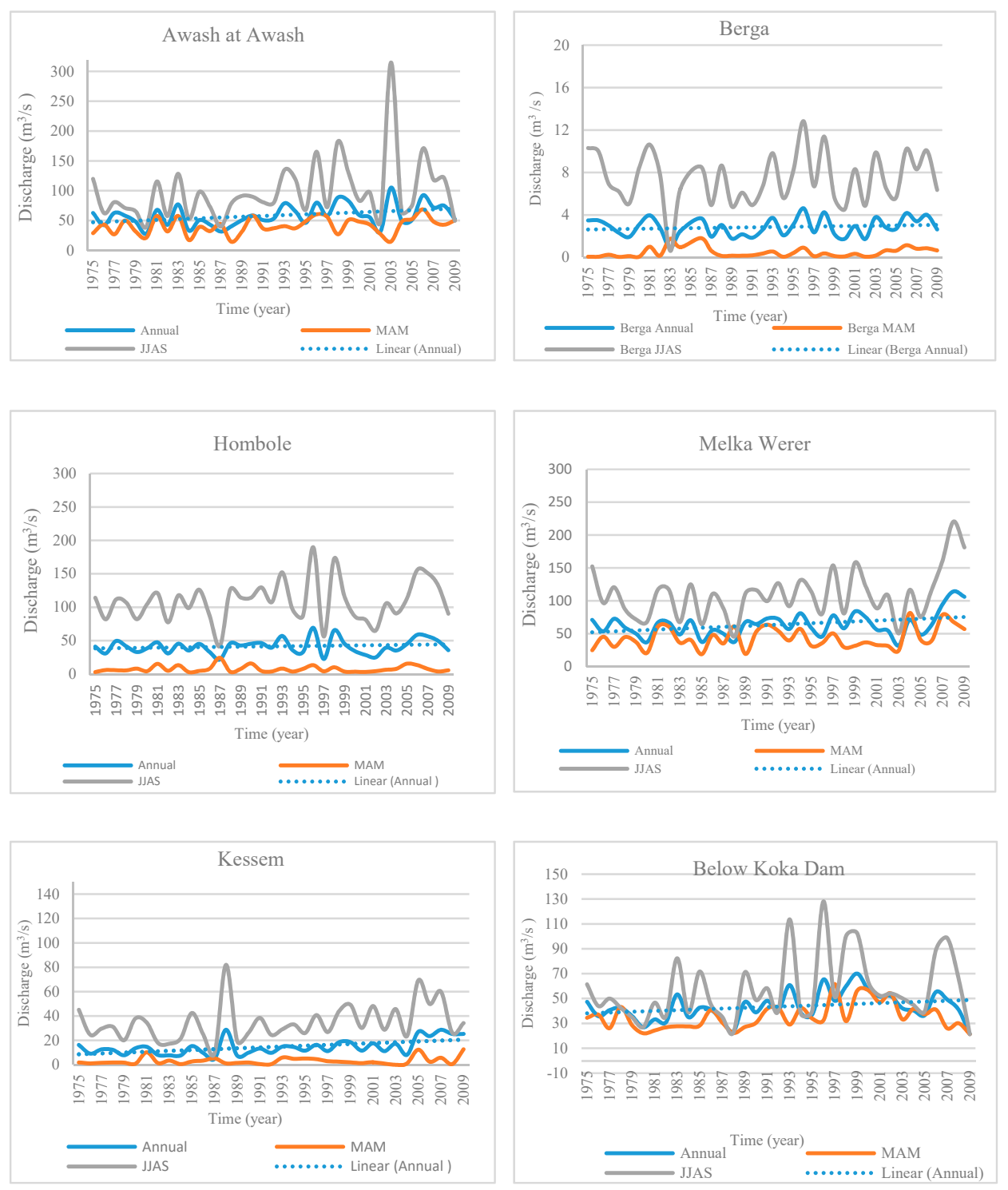

Figure 9. The temporal variability in the annual and seasonal streamflow in the ARB, (Group 1) (1975-2008).
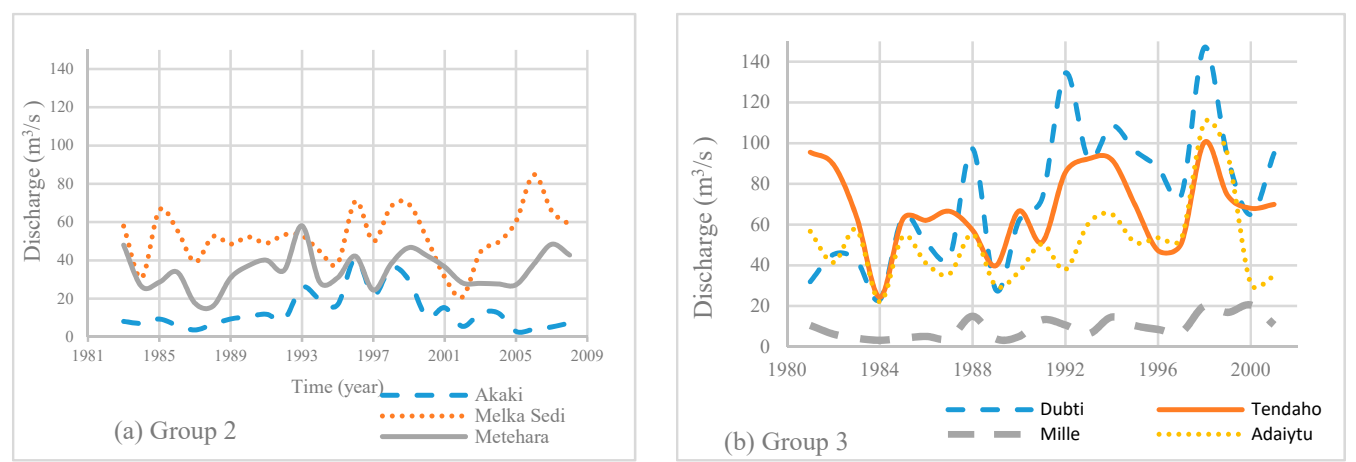

Figure 10. Temporal annual and seasonal streamflow variability in the ARB; Group 2 (1983-2008), and Group 3 (1981-2001).

Table 2 gives the summary of descriptive statistics of the 18 streamflow stations. The annual streamflow in the majority of the stations indicated a Z-score of Skewness and Kurtosis closer to zero, indicating no significant difference from normality, while four stations slightly deviated from the range. 
About $5.6 \%, 27.8 \%$ and $66.7 \%$ of the stations showed normal $(C V<20)$, moderate $(C V$ of $20-30)$ and high $(C V>30)$ variability of streamflow, respectively (Table 2$)$. Seasonal streamflow variability was tested for similar periods as rainfall seasonality (JJAS and MAM) analysis. The streamflow in MAM and JJAS showed a high CV at $94.4 \%$ of the stations. Only one station for each season showed a moderate variability, with a CV of $28.7 \%$ and $29.1 \%$ at Wonji in MAM and at Hombole in JJAS, respectively.

Table 2. Summary of descriptive statistics of streamflow in the ARB.

\begin{tabular}{|c|c|c|c|c|c|c|c|c|c|}
\hline \multirow[b]{2}{*}{ No } & \multirow[t]{2}{*}{ Station } & \multicolumn{4}{|c|}{ Annual } & \multicolumn{2}{|c|}{ MAM } & \multicolumn{2}{|c|}{ JJAS } \\
\hline & & $\begin{array}{l}\text { Mean } \\
(\mathrm{mm})\end{array}$ & $C V(\%)$ & Kurtosis & Skewness & $\begin{array}{l}\text { Mean } \\
(\mathrm{mm})\end{array}$ & $C V(\%)$ & $\begin{array}{l}\text { Mean } \\
(\mathrm{mm})\end{array}$ & $C V(\%)$ \\
\hline 1 & Adaiytu & 51.07 & 40.41 & 2.81 & 1.47 & 36.01 & 44.39 & 68.80 & 58.58 \\
\hline 2 & Akaki & 13.00 & 75.91 & 1.99 & 1.58 & 4.68 & 99.70 & 29.54 & 74.87 \\
\hline 3 & Awash@Awash & 58.45 & 31.36 & 0.00 & 0.55 & 40.70 & 33.55 & 98.41 & 53.16 \\
\hline 4 & Below Koka Dam & 43.79 & 25.96 & -0.01 & 0.45 & 35.80 & 38.31 & 59.32 & 42.90 \\
\hline 5 & Berga & 2.85 & 30.88 & -0.58 & 0.06 & 0.47 & 99.38 & 7.42 & 33.71 \\
\hline 6 & Dubti & 72.36 & 40.53 & 0.37 & 0.55 & 53.06 & 48.07 & 104.46 & 58.86 \\
\hline 7 & Holeta & 1.73 & 56.29 & 8.78 & 2.57 & 0.29 & 74.41 & 4.28 & 56.62 \\
\hline 8 & Hombole & 41.51 & 26.89 & 0.26 & 0.52 & 7.64 & 63.63 & 108.84 & 28.70 \\
\hline 9 & Keleta & 58.45 & 31.36 & 0.00 & 0.55 & 40.70 & 33.55 & 98.41 & 53.16 \\
\hline 10 & Kessem & 14.60 & 44.61 & -0.12 & 0.85 & 3.21 & 99.04 & 34.65 & 43.74 \\
\hline 11 & Melka Kuntire & 28.14 & 30.47 & 0.32 & 0.93 & 3.25 & 72.02 & 76.48 & 31.90 \\
\hline 12 & Melka Sedi & 53.69 & 26.23 & 0.27 & -0.19 & 40.29 & 43.85 & 84.15 & 30.73 \\
\hline 13 & Melka werer & 66.14 & 32.45 & 2.08 & 1.14 & 47.03 & 47.56 & 110.55 & 34.41 \\
\hline 14 & Metehara & 34.07 & 28.60 & 0.05 & 0.40 & 24.23 & 30.79 & 54.93 & 38.36 \\
\hline 15 & Mille & 13.76 & 139.38 & 22.37 & 4.55 & 10.16 & 103.43 & 23.08 & 155.82 \\
\hline 16 & Mojo & 18.09 & 113.29 & 11.40 & 3.03 & 6.85 & 333.31 & 42.61 & 84.56 \\
\hline 17 & Tendaho & 69.70 & 27.09 & -0.42 & -0.26 & 63.16 & 58.91 & 94.87 & 50.55 \\
\hline 18 & Wonji & 43.33 & 19.35 & -0.91 & 0.16 & 35.61 & 29.06 & 56.78 & 35.46 \\
\hline
\end{tabular}

CV: Coefficient of variation.

\subsection{Hydro-Climatic Trend Analysis}

\subsubsection{Rainfall}

The summary of rainfall trend analysis using MK test and Sen's slope estimator is shown in Table 3. The MK analysis presented a significant $(0.01$ and 0.05$)$ annual rainfall trend at seven stations, while five of the stations showed a negative trend. The positive annual significant $(0.01)$ trend was observed at two stations, Koka Dam and Melkasa. The JJAS rainfall indicated a significant (0.05 and 0.01) trend at eight stations, while three of the stations showed a positive significant trend. The MAM rainfall showed a significant $(0.05$ and 0.01$)$ trend at four stations. In MAM rainfall, only one station showed a positive significant trend at $5 \%$ significance level. Furthermore, a negative $Z s$ value was detected in about $71.43 \%, 64.28 \%$ and $53.57 \%$ of the stations in annual, MAM and JJAS seasons, respectively.

Table 3. Summary of rainfall trend test using Mann-Kendall and Sen's Slope in ARB.

\begin{tabular}{|c|c|c|c|c|c|c|c|}
\hline \multirow{2}{*}{ No } & \multirow{2}{*}{ Station } & \multicolumn{2}{|l|}{ Annual } & \multicolumn{2}{|l|}{ MAM } & \multicolumn{2}{|l|}{ JJAS } \\
\hline & & $Z_{S}$ & Sen's Slope & $Z_{S}$ & Sen's Slope & $Z_{S}$ & Sen's Slope \\
\hline 1 & Abomassa & -1.065 & -2.65 & -1.094 & -1.53 & 1.577 & 3.33 \\
\hline 2 & Adaiytu & -1.616 & -4.23 & $-2.908^{* *}$ & $-4.18^{* *}$ & 0.765 & 1 \\
\hline 3 & Addis Ababa Bole & $-2.123 *$ & $-3.03^{* *}$ & 0.249 & 0.14 & $-2.527 * *$ & $-2.06 *$ \\
\hline 4 & Addis Alem & $-2.037^{*}$ & $-4.43 *$ & -1.246 & -0.95 & -1.537 & -2.68 \\
\hline 5 & Akaki & -0.913 & -1.29 & 1.014 & 0.51 & -0.492 & -0.51 \\
\hline 6 & Aleltu & -0.232 & -0.97 & -1.131 & -2.24 & 0.17 & 0.68 \\
\hline 7 & Aliyu Amba & -1.005 & -3.5 & -1.48 & -1.99 & 0.729 & 1.06 \\
\hline 8 & Debire Zeyit & -1.346 & -2.13 & 0.115 & 0.06 & $-2.086^{*}$ & $-2.31 *$ \\
\hline 9 & Dibre Sina & $-6.267^{* *}$ & $-31.31^{* *}$ & $-4.902 * *$ & $-8.17^{* *}$ & $-5.669 * *$ & $-15.53^{* *}$ \\
\hline 10 & Dire Dawa & 0.583 & 0.64 & 1.713 & 1.13 & -0.566 & -0.27 \\
\hline 11 & Gewane & 0.769 & 2.56 & -0.957 & -1.85 & $2.382 *$ & $6.39 *$ \\
\hline
\end{tabular}


Table 3. Cont.

\begin{tabular}{lccccccc}
\hline \multirow{2}{*}{ No } & Station & Annual & \multicolumn{3}{c}{ MAM } & \multicolumn{3}{c}{ JJAS } \\
\cline { 3 - 7 } & & $Z_{S}$ & Sen's Slope & $Z_{S}$ & Sen's Slope & $Z_{S}$ & Sen's Slope \\
\hline 12 & Ginchi & -1.42 & -3.56 & -1.392 & -2.25 & -0.057 & -0.06 \\
13 & Holeta & $-2.455^{*}$ & $-3.68^{*}$ & -1.761 & -1.19 & $-2.164^{*}$ & $-2.46^{*}$ \\
14 & Kimoye & -1.73 & -5.47 & -0.477 & -1.06 & -1.594 & -3.17 \\
15 & Koka dam & $2.990^{* *}$ & $8.22^{* *}$ & $4.120^{* *}$ & $4.86^{* *}$ & $3.286^{* *}$ & $6.74^{* *}$ \\
16 & Kombolcha & -0.819 & -1.05 & -0.675 & -0.61 & 1.081 & 1.38 \\
17 & Kulumsa & -0.293 & -0.35 & 0.222 & 0.2 & -0.382 & -0.24 \\
18 & Majete & 0.024 & 0.15 & -0.805 & -0.63 & 0.481 & 0.88 \\
19 & Melkasa & $2.890^{* *}$ & $6.07^{* *}$ & 0.458 & 0.81 & $2.995^{* *}$ & $5.72 * *$ \\
20 & Mersa & -1.665 & -3.69 & $-2.416^{*}$ & $-2.7 *$ & 1.036 & 1.84 \\
21 & Metehara & -1.67 & -3.17 & -1.67 & -2.23 & -0.081 & -0.28 \\
22 & Mille & -0.056 & -0.03 & 0.101 & 0.07 & -0.191 & -0.36 \\
23 & Mojo & 1.381 & 2.63 & 0.876 & 0.79 & 1.657 & 2.02 \\
24 & Shola Gebeya & -1.138 & -2.85 & -0.902 & -0.86 & -0.248 & -0.78 \\
25 & Tora showa & $-1.963^{*}$ & $-9.3 *$ & -0.749 & -2.09 & $-2.070^{*}$ & $-4.37^{*}$ \\
26 & Tulu Bolo & -0.85 & -1.67 & 0 & 0 & -0.328 & -0.8 \\
27 & Wuchale & 0.101 & 0.44 & -1.651 & -2.69 & 0.64 & 1.3 \\
28 & Ziway & 0.691 & 2.54 & -0.454 & -1.38 & 0.81 & 2.23 \\
\hline
\end{tabular}

$Z_{S}$ : Mann-Kendall test, ${ }^{* *}$ Significant at 0.01 significance level. ${ }^{*}$ Significant at 0.05 significance level.

\subsubsection{Streamflow}

The summary of streamflow trend analysis using MK test and Sen's slope estimator is shown in Table 4. The MK analysis presented a positive significant (0.01 and 0.05) annual streamflow trend at five stations. The highest positive annual significant (0.01) trend was observed at Kessem stations. The MAM streamflow showed a positive significant (0.05) trend at two stations and a negative significance trend at one station. In JJAS streamflow, only one station showed a positive significance trend at 5\% significance level. Furthermore, a positive $Z s$ value was detected in about $77.22 \%, 72.22 \%$ and $88.89 \%$ of the stations in annual, MAM and JJAS seasons, respectively. Moreover, in MAM, a negative $Z s$ value was indicated in three stations located in the Lower Awash Basin.

Table 4. The summary of streamflow trend using Mann-Kendell and Sen's slope test in the ARB.

\begin{tabular}{|c|c|c|c|c|c|c|c|}
\hline \multirow{2}{*}{ No } & \multirow{2}{*}{ Station } & \multicolumn{2}{|c|}{ Annual } & \multicolumn{2}{|c|}{ MAM } & \multicolumn{2}{|c|}{ JJAS } \\
\hline & & $Z_{S}$ & Sen's Slope & $Z_{S}$ & Sen's Slope & $Z_{S}$ & Sen's Slope \\
\hline 1 & Adaiytu & 0.574 & 0.46 & -1.661 & -0.64 & 1.359 & 1.84 \\
\hline 2 & Akaki & 0.652 & 0.13 & $2.391 *$ & $0.08^{*}$ & 0.336 & 0.21 \\
\hline 3 & Awash@Awash & $2.073 *$ & $0.65 *$ & 1.846 & 0.49 & 1.534 & 0.91 \\
\hline 4 & $\begin{array}{c}\text { Below Koka } \\
\text { dam }\end{array}$ & 0.314 & 0.04 & -0.435 & -0.06 & 1.406 & 0.35 \\
\hline 5 & Berga & 0.534 & 0.01 & 1.809 & 0.01 & 0.059 & 0 \\
\hline 6 & Dubti & 2.105 * & $1.36^{*}$ & 0.535 & 0.3 & 1.606 & 2.54 \\
\hline 7 & Holeta & -1.193 & -0.01 & 0.085 & 0 & -1.534 & -0.04 \\
\hline 8 & Hombole & 0.71 & 0.12 & 0.114 & 0 & 0.738 & 0.3 \\
\hline 9 & Keleta & $2.073 *$ & 0.65 * & 1.846 & 0.49 & 1.534 & 0.91 \\
\hline 10 & Kessem & $3.068 * *$ & $0.34 * *$ & 0.83 & 0.03 & $2.215 *$ & $0.47^{*}$ \\
\hline 11 & Melka Kuntire & 1.089 & 0.12 & 1.065 & 0.03 & 1.21 & 0.39 \\
\hline 12 & Melka sedi & 1.324 & 0.5 & 0.375 & 0.18 & 0.257 & 0.17 \\
\hline 13 & Melka Werer & $2.328 *$ & $0.72 *$ & 1.884 & 0.66 & 1.543 & 0.95 \\
\hline 14 & Metehara & 0.929 & 0.22 & $2.074 *$ & 0.38 * & 0.454 & 0.34 \\
\hline 15 & Mille & 1.418 & 0.23 & $-1.960 *$ & -0.21 * & 1.126 & 0.32 \\
\hline 16 & Mojo & -0.593 & -0.05 & -0.712 & -0.02 & -0.059 & 0 \\
\hline 17 & Tendaho & -0.442 & -0.2 & -1.054 & -0.87 & 0.068 & 0.24 \\
\hline 18 & Wonji & -0.314 & -0.03 & 1.709 & 0.13 & 0.253 & 0.08 \\
\hline
\end{tabular}

$Z_{S}$ : Mann-Kendall test, ${ }^{* *}$ Significant at 0.01 significance level. ${ }^{*}$ Significant at 0.05 significance level. 


\subsubsection{Relationship between Rainfall and Streamflow}

The annual rainfall and streamflow at six stations indicated a positive correlation coefficient which varied from 0.24 to 0.68 (Figure 11). The correlation coefficient was $0.5,0.55$ and 0.68 at Holetta, Addis Alem and Mille, respectively (Figure 11). By comparison, the correlation was low at two stations: Metehara (0.24) and Koka Dam (0.36). On the contrary, two stations (Adaiytu and Mojo) showed both a positive and negative relationship in a different time series. The current finding revealed the existence of a positive correlation in a majority of the tested stations.
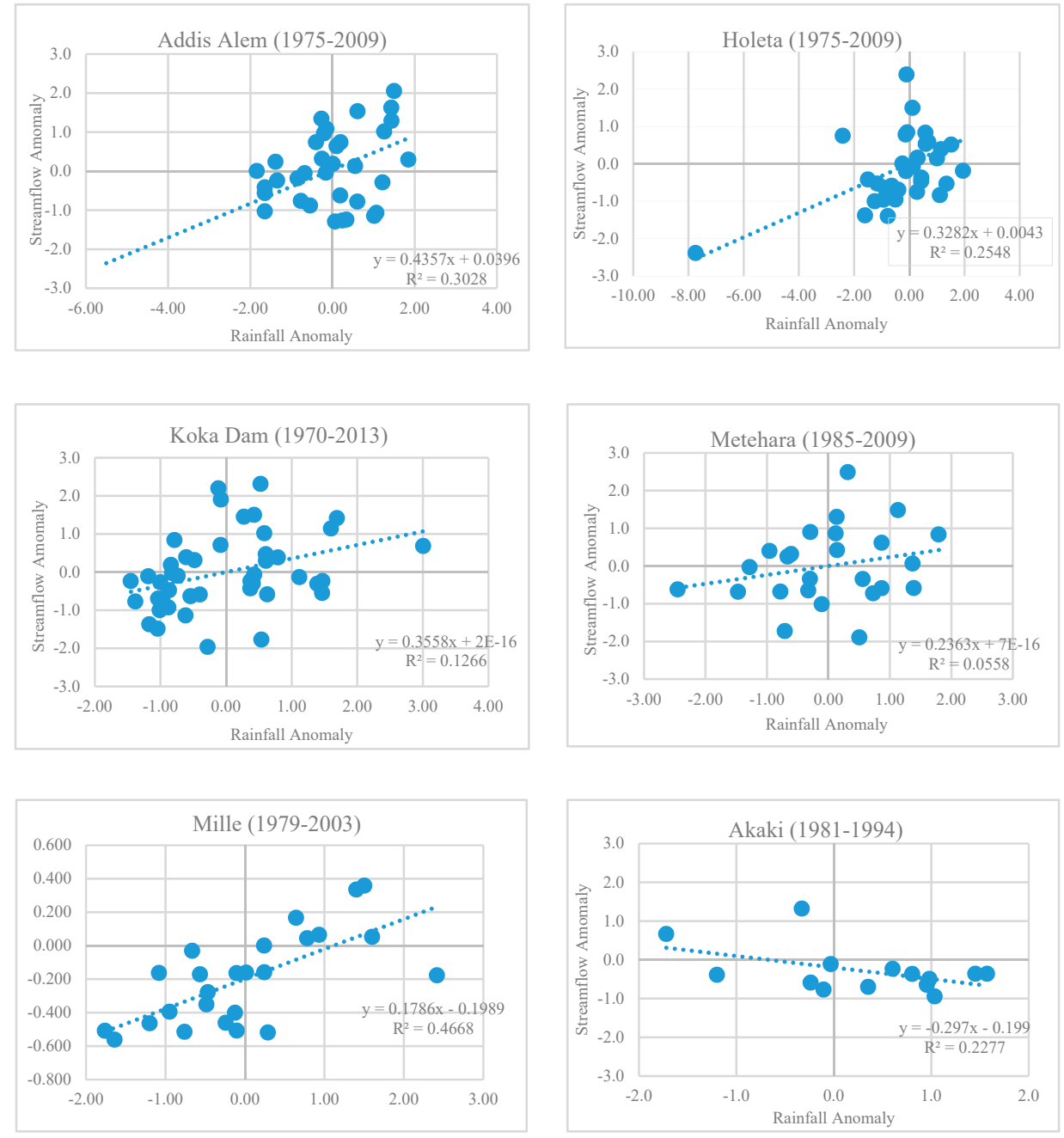

Figure 11. Relationship between rainfall and streamflow trend in the ARB.

\section{Discussion}

The mean monthly rainfall showed a bimodal pattern with two rainy seasons in the Middle Awash and Lower Awash, while unimodal rainfall was indicated in the Upper Awash. The two rainfall regimes in the Middle and Lower Awash occurred in JJAS and MAM, which presented the main and shorter rainy periods, respectively. Moreover, in all the rainfall stations, the minimum rainfall was recorded in December while the maximum rainfall occurred in August and September. These rainfall regimes coincide with the main agricultural seasons in Ethiopia, whereby agricultural production is predominantly reliant on rainfall. The study by $[16,24]$ indicated a similar rainfall pattern; which was unimodal rainfall in Upper Awash and a bimodal rainfall in the Middle Awash and Lower Awash.

The finding of this study indicated the occurrence of temporal variability with an increasing pattern in some stations, and a decreasing pattern in other stations. The JJAS rainfall showed slightly 
similar result as that of the annual rainfall variability. About $85.7 \%$ and $75.3 \%$ of the rainfall stations exhibited normal to moderate variability in annual and JJAS rainfall, respectively, whereas, $96.43 \%$ of rainfall stations showed a high variability in MAM. The rainfall variability has a direct influence on agricultural water availability and irrigation, especially for countries like Ethiopia, where $85 \%$ of the livelihood depends on agriculture. Additionally, the high rainfall variability aggravates the frequency of flood occurrence in this basin. Similarly, the study by [24] indicated the occurrence of flood and drought due to annual rainfall variability in the ARB. Additionally, the study by [17] indicated a variability of precipitation and streamflow with $8.49 \%$ and $34 \%$ coefficients of variation, respectively. The study of [17] also showed an increasing rainfall trend in Kiremt (JJA) and a decreasing rainfall trend in Meher (September to November), Bega (December to February) and Belg (MAM). The SAI in annual and seasonal time series indicated a negative anomaly in a closely similar proportion of the observations. Furthermore, the SAI result showed that most of the years exhibited negative anomaly in MAM rainfall, indicating drier period. Moreover, a lot of large- and small-scale irrigation schemes are found in ARB, especially in the middle Awash, which could be directly affected by low water availability during MAM. The occurrence of high rainfall and streamflow variability combined with the expansion of irrigation in ARB has an influence on agriculture and crop productivity, which aggravates the prevalence of food insecurity and drought in the basin.

The results in most of the streamflow stations revealed that river discharge was low during the months of November to June, but started to increase in July. Furthermore, in all stations, the peak flow occurred in August and September. The monthly river flow was low during the dry period and it started to increase in the rainy season. This meant that the available water supply was limited during the dry season when irrigation is required, and more in the rainy season when hardly any irrigation is needed. Similar to the monthly streamflow, the annual and MAM river discharge indicated a similar pattern except in a few years with extreme high flow records. Moreover, the results showed that the annual temporal variability of streamflow exhibited a positive trend in fourteen stations and a negative trend in four stations.

The Awash River is the major water supply in the ARB that provides regular irrigation water to productive and larger agricultural areas. The high variability during the period MAM and JJAS affects the streamflow level, frequency and the occurrence of extreme hydrological events. As the streamflow variability becomes higher and the water demand increases, water shortage becomes a major threat unless there are adequate water conservation structures and proper water management approaches in this basin. In recent years, there has been significant expansion of irrigation activities in this basin, especially in Upper and Middle Awash region. Furthermore, flood and drought have become major challenges in the ARB $[5,16]$. The MK trend test indicated a significant $(0.01$ and 0.05$)$ rainfall trend in seven, four and eight stations in annual, MAM and JJAS seasons, respectively. The MK test showed that most of the significant trends in annual rainfall were decreasing except in two stations. Moreover, the negative $Z s$ and Sen's slope estimator values were detected in about $71.43 \%, 64.28 \%$ and $53.57 \%$ of the stations in annual, MAM and JJAS seasons, respectively, indicating a decreasing rainfall trend. Both the graphical and MK test showed a decreasing trend in most of the rainfall stations, indicating a decline in water availability in ARB.

In addition, the MK test showed a significant (0.01 and 0.05) streamflow trend in five, one and three stations in annual, JJAS and MAM seasons, respectively. Furthermore, a positive Zs and Sen's slope estimator values were detected in the majority of the stations in annual, MAM and JJAS seasons, indicating an increasing streamflow trend. However, in MAM, a decreasing streamflow trend was detected in Lower Awash at three stations. The streamflow trend in ARB relates to the level of Awash River that contributes to the water availability in this basin. The increasing trend leads to frequent occurrence of peak flows, which aggravates flooding in the area. Furthermore, the results indicated a decreasing streamflow trend in few stations in the Middle Awash and Lower Awash. This low river flow indicated a decline in water availability, which affects the irrigation water supply and also other water use in the ARB, especially in the lower part. The Awash River flow reduction might be related 
to irrigation expansion in the Upper and Middle Awash, improper water-abstraction, poor water management, climatic factors, population density and environmental change.

The relationship between rainfall and streamflow trends in six stations showed a positive correlation coefficient with relatively good correlation $(>0.5)$ in three stations and poor correlation $(<0.4)$ in two stations. The correlation observed at the two stations, below Koka dam and Mille, might be affected due to the monitoring effect of Koka and Tendaho reservoirs, respectively. Moreover, the rainfall-streamflow trends showed that rainfall was not the only factor that influenced the variability and availability of streamflow in this basin. Further research is recommended to investigate other factors that influence variability in Awash River flow and the rainfall-streamflow relationships, for instance: the density of physical properties, watershed characteristics and environmental factors like vegetation cover.

\section{Conclusions}

The objective of this study was to characterise, quantify and validate the variability and trends of hydro-climatic variables in the ARB in Ethiopia using graphical and statistical methods. The rainfall and streamflow trends and their relationships were analysed using regression method, MK test and correlation analysis. The main findings of this research are summarised as follows:

1. A bimodal pattern with two rainy seasons was displayed in the mean monthly rainfall in the Middle and Lower Awash, while the pattern in the Upper Awash was unimodal. In the majority of the stations, the rainfall exhibited from normal to moderate variability in the mean annual and the JJAS period, whereas it was highly variable in almost all stations during the MAM rainfall season.

2. High streamflow variability was observed in MAM and JJAS periods. Besides, the monthly river flow was low during the dry season of the year, but started to increase in the rainy season. Shortage of rainfall in MAM and low monthly streamflow during the dry period leads to a decline in water supply in ARB.

3. The MK trend test showed that most of the significant trends in annual rainfall were decreasing. The negative $Z s$ and Sen's slope estimator values were detected in about $71.43 \%, 64.28 \%$ and $53.57 \%$ of the stations in annual, MAM and JJAS seasons respectively, indicating a decreasing rainfall trend. Both the graphic and MK test indicated a decreasing trend in most of the stations, which may result in a decrease in water availability in ARB.

4. The MK trend test revealed an increasing annual streamflow trend in $27.8 \%$ of the stations, whereas, in the MAM period, a decreasing trend was displayed in the Lower Awash at three stations. Moreover, a positive Zs and Sen's slope estimator values were observed in majority of the stations in annual, MAM and JJAS seasons, indicating an increasing streamflow trend. An increasing trend was shown in most of stations in Upper and Middle Awash, whereas a decreasing trend was revealed in Lower Awash.

5. The trend relationship between rainfall and streamflow in six stations indicated a positive correlation coefficient, with slightly good correlation in four stations and poor correlation in two stations. The correlation observed downstream of Koka and Tendaho dams might be affected due to the monitoring effect of Koka and Tendaho reservoirs, respectively. Moreover, the rainfall-streamflow trend relationship showed that rainfall was not the only factor that influenced the variability and availability of streamflow in this basin. The other factors that influence variability in Awash River flow and the rainfall-streamflow relationship includes physical property, watershed characteristics and environmental factors, like vegetation cover, which still needs further assessment.

The findings of this study provide valuable information on the characteristics and variability of rainfall and streamflow necessary for planning and designing of sustainable water management strategies and minimizing the impact of droughts and floods in the ARB. The cause of an increasing 
trend in streamflow might be urbanisation, land degradation, population density and climatic factors. However, the declining trend might be related to irrigation expansion in Upper and Middle Awash, improper water-abstraction and poor water management, climatic factors and environmental changes in the basin. Therefore, further assessment on factors influencing the variability and availability of Awash River flow is needed in order to implement a sustainable water management strategy and also to mitigate the adverse effects of water scarcity and extreme events on the food security, livelihoods, environment and overall development of the country. Additionally, further research on river water management and water saving techniques is recommended to cope with the high variability of river flow and rainfall in this basin.

Author Contributions: Conceptualization, L.K., R.K. and M.T.T.; methodology, M.T.T.; software, M.T.T.; validation, L.K., R.K. and B.Z.; formal analysis, M.T.T.; investigation, L.K., R.K. and M.T.T.; resources, L.K.; data curation, L.K. and M.T.T.; Writing-original draft preparation, M.T.T.; writing—review and editing, L.K., R.K. and B.Z.; visualization, L.K. and M.T.T.; supervision, L.K. and R.K.; project administration, L.K.; funding acquisition, L.K.

Funding: This research was funded by International Postgraduate Research Award (IPRA) of University of New England (UNE), Armidale, Australia.

Acknowledgments: The authors are grateful to UNE in Australia for providing postgraduate research support to the first author, and NMA, MWIEE and EIAR in Ethiopia for their support.

Conflicts of Interest: The authors declare no conflicts of interest.

\section{Appendix A}

Table A1. Location of Rainfall stations in Awash River Basin.

\begin{tabular}{ccc}
\hline & Rainfall Stations & \\
\hline Upper Awash & Middle Awash & Lower Awash \\
\hline Addis Ababa Bole & Abomssa & Adaiytu \\
Addis Alem & Aleltu & Kombolcha \\
Akaki & Aliyu Amba & Merssa \\
Debre Zeit & Debre Sina & Mille \\
Ginchi & Dire Dawa & Wuchale \\
Holetta & Gewane & \\
Kimoye & Majete & \\
Koka Dam & Metehara & \\
Kulumsa & Shola Gebeya & \\
Melkasa & & \\
Mojo & & \\
Tulu Bolo & & \\
\hline
\end{tabular}

Table A2. Classification of Streamflow Stations in Awash River Basin.

\begin{tabular}{ccc}
\hline & Streamflow Stations \\
\hline Group-1 & Group-2 & Group-3 \\
\hline 1975-2009 & 1983-2008 & 1981-2001 \\
Awash@ Awash & Akaki & Adaiytu \\
Below Koka Dam & Melka sedi & Dubti \\
Berga & Metehara & Mille \\
Holetta & & Tendaho \\
Hombole & & \\
Keleta & & \\
Kessem Awera melka & & \\
Melka Kuntire & \\
Melka Werer & \\
Mojo & \\
Wonji & \\
\hline
\end{tabular}


Table A3. Classification of Rainfall Stations in Awash River Basin.

\begin{tabular}{cccc}
\hline \multicolumn{4}{c}{ Rainfall Stations } \\
\hline Group-1 & Group-2 & Group-3 & Group-4 \\
\hline 1954-2013 & 1965-2016 & 1975-2004 & $1985-2012$ \\
Addis Ababa Bole & Addis Alem & Aleltu & Abomasa \\
Akaki & Aliyu Amba & Wuchale & Adaiytu \\
Debre Zeyit & Kombolcha & Tora showa & Gewane \\
Dire Dawa & Debre Sina & Holetta & Ginchi \\
& Koka Dam & Kulumsa & Kimoye \\
& Mojo & Mille & Melkasa \\
& Tulubolo & Mersa & Metehara \\
& & Majete & SholaGebeya \\
& & & Ziway \\
\hline
\end{tabular}

\section{References}

1. Niang, I.; Ruppel, O.C.; Abdrabo, M.A.; Essel, A.; Lennard, C.; Padgham, J.; Urquhart, P. Africa. In Climate Change 2014: Impacts, Adaptation, and Vulnerability. Part B: Regional Aspects. Contribution of Working Group II to the Fifth Assessment Report of the Intergovernmental Panel on Climate Change; Cambridge University Press: Cambridge, UK; New York, NY, USA, 2014; pp. 1199-1265.

2. Wang, M.; Xia, J. Impact of Climate Fluctuation and Land-Cover Changes on Runoff in the Yellow River Basin; IAHS-AISH Publication: Iguacu, Brazil, 2005.

3. Beven, K.J. Rainfall-Runoff Modelling: The Primer; John Wiley \& Sons: Hoboken, NJ, USA, 2011.

4. Mosello, B.; Calow, R.; Tucker, J.; Parker, H.; Alamirew, T.; Kebede, S.; Alemseged, T.; Gudina, A. Building Adaptive Water Resources Management in Ethiopia; Overseas Development Institute: London, UK, 2015.

5. Global Green Growth Institute. Water Resources and Extreme Events in the Awash Basin: Economic Effects and Policy Implications; Vivid Economics: London, UK, 2016.

6. World Bank. Ethiopia: Managing Water Resources to Maximize Sustainable Growth; Agriculture and Rural Development Department: Washington, DC, USA, 2006.

7. Stuart Orr, C.A.; Dave, T. Understanding Water Risks: A Primer on the Consequences of Water Scarcity for Government and Business; WWF Water Security Series; World Wildlife Fund (WWF): Washington, DC, USA, 2009.

8. Asfaw, A.; Simane, B.; Hassen, A.; Bantider, A. Variability and time series trend analysis of rainfall and temperature in northcentral Ethiopia: A case study in Woleka sub-basin. Weather Clim. Extrem. 2018, 19, 29-41. [CrossRef]

9. Cheung, W.H.; Senay, G.B.; Singh, A. Trends and spatial distribution of annual and seasonal rainfall in Ethiopia. Int. J. Clim. 2008, 28, 1723-1734. [CrossRef]

10. Tesemma, Z.K.; Mohamed, Y.A.; Steenhuis, T.S. Trends in rainfall and runoff in the Blue Nile Basin: 1964-2003. Hydrol. Process. 2010, 24, 3747-3758. [CrossRef]

11. Wagesho, N.; Goel, N.; Jain, M. Temporal and spatial variability of annual and seasonal rainfall over Ethiopia. Hydrol. Sci. J. 2013, 58, 354-373. [CrossRef]

12. Alemayehu, A.; Bewket, W. Local spatiotemporal variability and trends in rainfall and temperature in the central highlands of Ethiopia. Geogr. Ann. Ser. A Phys. Geogr. 2017, 99, 85-101. [CrossRef]

13. Mengistu, D.; Bewket, W.; Lal, R. Recent spatiotemporal temperature and rainfall variability and trends over the Upper Blue Nile River Basin, Ethiopia. Int. J. Clim. 2014, 34, 2278-2292. [CrossRef]

14. Kassie, B.T.; Rötter, R.P.; Hengsdijk, H.; Asseng, S.; Van Ittersum, M.K.; Kahiluoto, H.; Van Keulen, H.; Van Ittersum, M. Climate variability and change in the Central Rift Valley of Ethiopia: Challenges for rainfed crop production. J. Agric. Sci. 2013, 152, 58-74. [CrossRef]

15. Bekele, D.; Alamirew, T.; Kebede, A.; Zeleke, G.; Melese, A.M. Analysis of rainfall trend and variability for agricultural water management in Awash River Basin, Ethiopia. J. Water Clim. Chang. 2017, 8, 127-141. [CrossRef] 
16. Tiruneh, Y.; Berhanu, B.; Ayanew, S.; Tamrat, I.; Tesfaye, Y. Coping with Water Scarcity, the Role of Agriculture. Developing a Water Audit for Awash River Basin, Synthesis Report; Food and Agriculture Organization of the United Nations: Addis Ababa, Ethiopia, 2013.

17. Gedefaw, M.; Wang, H.; Yan, D.; Song, X.; Yan, D.; Dong, G.; Wang, J.; Girma, A.; Ali, B.A.; Batsuren, D.; et al. Trend Analysis of Climatic and Hydrological Variables in the Awash River Basin, Ethiopia. Water 2018, 10, 1554. [CrossRef]

18. Berhe, F.; Melesse, A.; Hailu, D.; Sileshi, Y.; Melesse, A. MODSIM-based water allocation modeling of Awash River Basin, Ethiopia. CATENA 2013, 109, 118-128. [CrossRef]

19. Gizaw, M.S.; Biftu, G.F.; Gan, T.Y.; Moges, S.A.; Koivusalo, H. Potential impact of climate change on streamflow of major Ethiopian rivers. Clim. Chang. 2017, 143, 371-383. [CrossRef]

20. Seleshi, Y.; Zanke, U. Recent changes in rainfall and rainy days in Ethiopia. Int. J. Clim. 2004, 24, 973-983. [CrossRef]

21. Taddese, G.; Sonder, K.; Peden, D. The Water of the Awash River Basin a Future Challenge to Ethiopia; International Livestock Research Institute: Addis Ababa, Ethiopia, 2003.

22. Girma, M.M.A.; Seleshi, B. Irrigation Practices in Ethiopia: Characteristics of Selected Irrigation Schemes; IWMI Working Paper 124; IWMI: Colombo, Sri Lanka, 2007.

23. McCuen, R.H. Hydrologic Analysis and Design, 2nd ed.; University of Maryland: College Park, MD, USA, 1998.

24. Edossa, D.C.; Babel, M.S.; Gupta, A.D. Drought analysis in the Awash River Basin, Ethiopia. Water Resour. Manag. 2010, 24, 1441-1460. [CrossRef]

25. Hailemariam, K. Impact of climate change on the water resources of Awash River Basin, Ethiopia. Clim. Res. 1999, 12, 91-96. [CrossRef]

26. Bewket, W.; Conway, D. A note on the temporal and spatial variability of rainfall in the drought-prone Amhara region of Ethiopia. Int. J. Clim. 2007, 27, 1467-1477. [CrossRef]

27. Katz, R.W.; Glantz, M.H. Anatomy of a rainfall index. Mon. Weather Rev. 1986, 114, 764-771. [CrossRef]

28. Kendall, M. Rank Correlation Methods; Charles Griffin: London, UK, 1975.

29. Mann, H.B. Nonparametric tests against trend. Econometrica: J. Econometric Soc. 1945, 13, 245-259. [CrossRef]

30. Yue, S.; Pilon, P.; Phinney, B.; Cavadias, G. The influence of autocorrelation on the ability to detect trend in hydrological series. Hydrol. Process. 2002, 16, 1807-1829. [CrossRef]

31. Hamed, K.H. Trend detection in hydrologic data: The Mann-Kendall trend test under the scaling hypothesis. J. Hydrol. 2008, 349, 350-363. [CrossRef]

32. Gocic, M.; Trajkovic, S. Analysis of changes in meteorological variables using Mann-Kendall and Sen's slope estimator statistical tests in Serbia. Glob. Planet. Chang. 2013, 100, 172-182. [CrossRef] 